\title{
The Commission as a Party before the Court - Reflections on the Complementarity Arrangement
}

\section{A Rudman*}

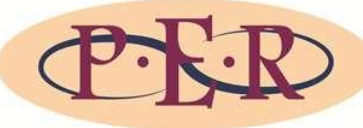

Author

Annika Rudman

Affiliation

University of Stellenbosch, South Africa

Email arudman@sun.ac.za

Date published 30 May 2016

Editor Prof AA du Plessis

How to cite this article

Rudman A "The Commission as a Party before the Court -

Reflections on the

Complementarity Arrangement" PER / PELJ 2016(19) - DOI http://dx.doi.org/10.17159/17273781/2016/v19i0a1225

Copyright

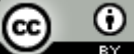

This work is licensed under a Creative Commons Attribution 4.0 International License.

DOI

http://dx.doi.org/10.17159/1727-

3781/2016/v19i0a1225

\begin{abstract}
The African Commission on Human and Peoples' Rights has worked as the continent's watchdog, under the ACHPR, for almost 30 years. Much has changed since the time of its inception. More institutions, set to ensure the implementation of the ACHPR, have been added. As the African Court on Human and Peoples' Rights became operational, a two-tiered human rights system was created.
\end{abstract}

This article explores the inter-relationship between the ACHPR, the Protocol Establishing the African Court on Human and Peoples' Rights and the Procedural Rules of these two institutions within the specific context of the African Commission's mandate to refer communications to the African Court. The aim is to offer a purposeful interpretation of the Procedural Rules governing referrals, guided by the understanding of the principle of complementarity in the preparatory works. The author argues that an appropriate interpretation of complementarity, within the context of referrals, becomes vital in alleviating one of the long-term plagues of the African, protective, human rights system, namely the lack of resources and human capital. It is suggested that the African Commission and the African Court can only be effective if they take proper cognisance of the principle of complementarity, in referring and receiving communications.

\section{Keywords}

African Charter on Human and Peoples' Rights; African Commission on Human and Peoples' Rights; African Court on Human and Peoples' Rights; referrals; complementarity; human rights; gross violations of human rights; individual communications. 


\section{Introduction}

The African Commission on Human and Peoples' Rights (hereafter the Commission) has worked as the continent's watchdog, under the African Charter on Human and Peoples' Rights ${ }^{1}$ (hereafter the ACHPR), for almost 30 years. Much has changed since the time of its inception. The respect for human rights, conceived as a means mainly to promote international cooperation, in the Charter of Organisation of African Unity ${ }^{2}$ (hereafter the OAU Charter), now constitutes one of the main objectives of the African Union (hereafter the $\mathrm{AU}$ ). ${ }^{3}$ More institutions set to ensure the implementation of the ACHPR have been added. The Protocol Establishing the Court on Human and Peoples' Rights (hereafter the Protocol) was adopted in 1998 and came into force in 2004. As the African Court on Human and Peoples' Rights (hereafter the Court) became operational, a two-tiered human rights system was created. ${ }^{4}$ Presently, the Commission and the African Committee on the Rights and Welfare of the Child ${ }^{5}$ are the main human rights institutions populating the African human rights structure, together with the Court.

The jurisdiction of the Court extends to all cases and disputes submitted to it concerning the interpretation and application of the ACHPR, the Protocol and any other relevant human rights instrument ratified by the states concerned. 6 The mandate of the Commission encompasses the interpretation of all provisions of the ACHPR as well as ensuring the protection of human and peoples' rights under conditions laid down by the ACHPR. ${ }^{7}$ Furthermore, both institutions have the mandate to receive individual and inter-state ${ }^{8}$ complaints concerning human rights violations. In this regard it is clear that there is considerable overlap in the jurisdiction and locus standi of these two institutions.

\footnotetext{
Annika Rudman. LLB LLM (Lund), PhD (Gothenburg). Professor, Department of Public Law, Faculty of Law, University of Stellenbosch, South Africa. E-mail: arudman@sun.ac.za.

African Charter on Human and Peoples' Rights (1981).

Charter of the Organisation of African Unity (1963).

Article 2(1)(e) of the OAU Charter and arts 3(h) and 4(m) of the Constitutive Act of the African Union (2000).

Viljoen 2004-2005 Brook J Int'I L 22.

Not discussed further in this article.

Article 3 of the Protocol to the African Charter on Human and People's Rights on the Establishment of a Court on Human and People's Rights (1998).

Article 45 (2) and (3) ACHPR.

I shall not make any further reference to this type of complaint in this article.
} 
Moreover, article 5(1)(a) of the Protocol provides the Commission with locus standi to bring cases before the Court. Direct access to the Court by individuals and NGOs with observer status before the Commission is restricted by state parties' express consent under article 34(6) of the Protocol. Therefore, the Commission has a very important role to perform as a conduit to the Court in cases where the original complainants lack direct access to the Court. ${ }^{9}$

The coexistence of multiple institutions set up to protect and uphold the human rights provided in the ACHPR necessitates a relationship between the relevant institutions. The principle set to govern this relationship is the principle of complementarity, as tellingly described by Clapham ${ }^{10}$ as a "notion in motion". Considering on the one hand the over-lapping jurisdictions of the Commission and the Court and on the other the important role the Commission could play as a party before the Court, an appropriate understanding of the meaning of complementarity, as the principle set to guide this interaction, becomes essential.

Complementarity is referred to in the preamble to the Protocol as well as in articles 2 and 8 . Article 2 stipulates that the Court should complement the protective mandate of the Commission, while the Preamble speaks to the point of the reinforcement of the efforts of the Commission under its protective mandate. Article 8 stipulates that:

The Rules of Procedure of the Court shall lay down the detailed conditions under which the Court shall consider cases brought before it, bearing in mind the complementarity between the Commission and the Court.

Articles 2 and 8 do not offer any further guidance to the meaning or application of "complementarity" but simply refer to the principle itself. Elsheikh ${ }^{11}$ suggests that because complementarity is such an abstract concept, left undefined in the Protocol, the Rules of Procedure of the Commission and the Court should give distinct, practical meaning to this concept. In 2002, when Elsheikh discussed this idea, the Procedural Rules of the Court and Commission ${ }^{12}$ had not yet been published. These rules

9 Thus far 8 states (Burkina Faso, Côte d'Ivoire, Ghana, Malawi, Mali, Rwanda, Tanzania and Benin) have made a declaration under art 34(6) of the Protocol. On the $24^{\text {th }}$ of February 2016, the government of Rwanda sent a note verbale officially withdrawing its declaration to the AU Commission and the African Court.

10 Clapham 2000 Hum Rts LJ 313.

11 Elsheikh 2002 AHRLJ 254.

12 Rules of Procedure of the African Commission on Human and Peoples' Rights (2010) (hereafter the Rules of the Commission); Rules of the African Court on Human and Peoples' Rights (2010) (hereafter the Rules of the Court). 
were issued only in 2010, six years after the Court became operational. Ebobrah $^{13}$ in his analysis of the reference to complementarity in the Rules of the Commission significantly concludes that "the rules have not gone too far beyond the instruments in explaining how the concept is to be applied in practice". In a situation where resources are scarce, it is important to promote an approach where the best-situated institution performs a mandate to the exclusion of the other in a determined hierarchy of oversight. Complementarity, if properly defined, has, as I argue further below, the potential of offering guidance in this regard.

\section{Scope}

As highlighted by Elsheikh ${ }^{14}$ and Ebobrah ${ }^{15}$ there have been on-going calls for procedural rules to help to delineate the meaning of complementarity in the relationship between the Commission and the Court. In this article I set out to explore the inter-relationship between the Protocol and the Procedural Rules of these two institutions within the specific context of the Commission's mandate to refer cases to the Court. Of specific interest is rule 118 of the Rules of the Commission, which indicate when and how the Commission can refer a complaint to the Court. The Commission's role as a conduit to the Court is fairly unchartered territory. There is no guidance in the Rules of the Commission as to whether individual complainants would, as in the Inter-American system, have any influence over the Commission's decision to refer a communication to the Court. To date the Commission has brought only three cases before the Court. ${ }^{16}$ At the time of writing only one of these cases had been finalised. ${ }^{17}$

It is the process under article 55 of the ACHPR, where individual complaints can be instituted, which mainly indicates the need for a referral as set out in rule 118 of the Rules of the Commission. The process before the Commission pertaining to an individual compliant submitted under article 55 of the ACHPR can be described in five general phases ${ }^{18}$; phase 1

\footnotetext{
Ebobrah 2011 EJIL 665.

Elsheikh 2002 AHRLJ 256.

Ebobrah 2011 EJIL 681.

African Commission on Human and Peoples' Rights v Libya Application No 004/2011 (finalised); African Commission on Human and Peoples' Rights v Kenya Application No 006/2012 (pending decision); African Commission on Human and Peoples' Rights $v$ Libya Application No 002/2013 (pending decision).

17 African Commission on Human and Peoples' Rights v Libya Application No 004/2011.

18 Rule 98 of the Rules of the Commission furthermore stipulates that the Commission can ask a state to adopt provisional measures "At any time after the receipt of a Communication and before a determination on the merits".
} 
registration; phase 2 consideration of locus standi'; phase 3 seizure;20 phase 4 considerations of admissibility ${ }^{21}$ and phase 5 considerations of the merits. ${ }^{22}$ As there is no provision in the Protocol that explicitly requires the Commission to conclude either on the admissibility or merits of a communication before submitting it to the Court, and the Court is competent to consider and decide the admissibility and merits of a case. A referral can take place at any stage of the process (phases $2-5)^{23}$ in accordance with rule 118 of the Rules of the Commission. Consequently, the referral of a case puts the spotlight on the principle of complementarity because it involves a risk of overlapping actions and reflects a need for a proper delineation of tasks and mandates.

The question I seek to address in this article is therefore whether referring a case before the consideration of admissibility is compatible with the principle of complementarity? Furthermore, is it beneficial, from the perspective of resource and time management, for the institutions involved to approach referrals in this fluent way, not requiring the mandate of each institution to complement the other? Should the Court perhaps utilise its mandate under article 6(1) of the Protocol to request the opinion of the Commission when deciding on the admissibility of cases instituted under article 5(3), to encourage the Commission to present its findings to the Court as it refers a case?

It is clear from the contents of rule 118 that different scenarios were considered and thus incorporated into the Rules of the Commission. Rule $118(1)$ stipulates a full consideration of the case ie including admissibility and merits; and rules 118(2), (3) and (4) indicate that a case can be referred either directly or after partial consideration. It is with regard to the latter rules

19 Viljoen International Human Rights Law in Africa 304.

20 Once a communication has been registered, the Commission has to be seized with it. Art 55 of the ACHPR provides that "Before each session of the Commission, the Secretary of the Commission prepares a list of all communications submitted to the Secretariat, other than those of State parties (...) and transmits them to the members of the Commission, who shall indicate which communications shall be considered by the Commission". Rule 102 (2) of the Rules of the Commission provides that "No communications concerning a State which is not a party to the Charter shall be received by the Commission or placed in a list".

21 Article 56 of the ACHPR.

22 The seizure, admissibility and merits of a communication are considered at separate meetings of the Commission. See for example Article 19 v Eritrea 2007 AHRLR 73 (ACHPR 2007) paras 10-42.

23 Arguably the Commission would not refer a case before it has registered it and concluded that the state party against which the complaint is brought is a party to the ACHPR and that the person or entity bringing the complaint is competent to do so. The ACHPR and the Rules of the Commission do not stipulate any "victim" requirement; see Viljoen International Human Rights Law in Africa 304. 
that the principle of complementarity could be used to guide the process of referrals. An appropriate interpretation of complementarity in the context of referrals, I argue, becomes essential in alleviating one of the long-term plagues of the African protective human rights system, namely the lack of resources and human capital. As we are now entrusted with a two-tiered system of human rights protection the procedure could, I argue, focus more on optimising the strengths of the two institutions involved rather than on trying to circumvent the Commission as far as possible. In this discussion I acknowledge that the fact-finding capacity of the Commission has not been utilised to its fullest potential and that it is essential to avoid the creation of new bottlenecks. ${ }^{24}$ However, as is suggested in the preparatory works (discussed under paragraph 3 below), a different role of the Commission could be envisaged. This is furthermore strengthened by a comparison with the functioning of the Inter-American Commission on Human Rights (hereafter the IACHR) and the Inter-American Court (hereafter the IAC) in the Inter-American human rights system.

The main assumption that guided this research was the idea that even though it seemed possible to refer a case at any stage under rules 118(2), (3) and (4), ignoring complementarity in this context would erode the Commissions functions. A referral without any consideration of the admissibility of a case would fail to effectively use the available resources and it would establish what Viljoen refers to as "Commission-mediated direct access" as the primary rule, not the exception. ${ }^{25}$ The main argument, in this regard, is that referring a case after admissibility has been confirmed could potentially decrease the duplication of processes, which would result in a more efficient burden sharing, a swifter process and less cost. ${ }^{26}$ The Court could limit its engagement with cases referred to it by the Commission to the merits, and explore the procedural side of cases only if it finds the recommendation of the Commission to be suspicious or even incorrect. The aim of this article is to offer a purposeful interpretation of rule 118 (2), (3) and (4) guided firstly by the understanding of the principle of complementarity in the preparatory works; and secondly as an outcome of the interaction between the two sets of Rules of Procedure, the Protocol and the ACHPR. To achieve this aim, the article is divided into 6 paragraphs. Paragraph 3 directs attention to the four draft protocols put forward in the process of establishing the current Protocol and the way the process of

Viljoen 2004-2005 Brook J Int'l L 32.

Viljoen 2004-2005 Brook J Int'l L 25.

26 Similar arguments were suggested by Viljoen and Murray before the conclusion of the Rules of Procedure of the Commission and Court. See Viljoen 2004-2005 Brook J Int'I L 32; and Murray 2002 AHRLJ 198-199. 
referrals was designed and finally concluded. Paragraph 4 provides brief comments on the system of referrals under the Inter-American system as a contrast to the African system. Paragraph 5 outlines and discusses the principles of complementarity in more detail within the context of the referral mechanism under the Rules of the Commission and the Court. The last paragraph is the concluding section of the article.

\section{Conceptions of complementarity in the drafting process of the Protocol}

The creation of a human rights system where both a commission and a court would exist complementarily to each other was envisaged at the inception of the ACHPR. ${ }^{27}$ However, it was later decided that the Commission would receive greater focus in order to get the promotional and protective human rights mandate off the ground. ${ }^{28}$ It is notable that further activity to establish the Court was generated not by the OAU but "by international human rights non-governmental organisations (...) such as the Geneva-based International Commission of Jurists (...), who prepared the early drafts of the Protocol". ${ }^{29}$ The impetus behind the creation of the first draft protocol was the ineffectual work of the Commission in the five years it had been operating, as seen through the lens of NGOs and human rights experts involved on the continent. ${ }^{30}$ The solution was a court that would give teeth to the ACHPR and serve as a more efficient institution than the Commission. Interestingly, as explained by Pityana ${ }^{31}$, the Commission did not initiate any of these activities and it committed itself to the Court only in 1998.

In 1994 the ICJ concluded the first draft protocol (hereafter the ICJ Protocol). ${ }^{32}$ This draft, established without any involvement of the state parties to the ACHPR, confirmed the centrality of the principle of complementarity. ${ }^{33}$ It also established the Commission as a party entitled to petition the Court. ${ }^{34}$ This position did not change during the continued drafting process. However, the requirements for such a petition and the

\footnotetext{
27 Pityana 2004 AHRLJ 121.

28 Pityana 2004 AHRLJ 121.

29 Pityana 2004 AHRLJ 121-122.

30 Pityana 2004 AHRLJ 122.

31 Pityana 2004 AHRLJ 122.

32 [ICJ] Draft Additional Protocol to the African Charter on Human and Peoples' Rights prepared by the experts assembled by the OAU General Secretariat in collaboration with the Commission on Human and Peoples' Rights and the International Commission of Jurists, 26-28 January 1994, Geneva, Switzerland (First Draft Additional Protocol to the African Charter On Human and Peoples' Rights (1994)).

33 Article 2 of the ICJ Protocol.

34 Article 18(1) of the ICJ Protocol.
} 
jurisdiction of the Court changed drastically throughout the following drafting process, once the state parties to the ACHPR got involved. Articles 2 and 19 of the ICJ Protocol set out the relationship between the Commission and the Court as well as the conditions for referrals. The relationship, as described in article 2, was characterised as "supplementary" as the Court should "supplement the protective mandate of the Commission". Furthermore, article 19(2) spelled out that the Court:

\begin{abstract}
[M]ay not consider a case originating from other communications [complaints from individuals and NGOs - author's comm.] and submitted to the Commission in accordance with article 55 of the Charter unless the Commission has considered the matter and made a determination. The Court may only deal with a case after the Commission has acknowledged the failure of efforts for a friendly settlement and within three months of a determination having been made by the Commission.
\end{abstract}

In the ICJ Protocol it is clear that, from the perspective of the human rights NGOs involved, the relationship between the two institutions was to be organised in such a way that the Commission's mandate to hear claims originating under article 55 of the ACHPR would not be superseded by the powers of the Court. The Commission first had to consider and decide on an individual communication before the Court would gain jurisdiction. Importantly, the Commission would not be able to transfer a case to the Court before it made a decision. The conditions for considering communications under the ICJ Protocol clearly had the effect of making the Commission the principal organ. The reference to "a determination" as the restriction relevant to article 55 complaints is therefore significant in the ICJ Protocol.

Furthermore, the ICJ Protocol opened up one important (direct) avenue for individuals, groups and NGOs to petition the Court. Under the ICJ Protocol it was proposed that the Court, notwithstanding article 19(2), could "on exceptional grounds, authorise persons, non-governmental organisations and groups of individuals to bring cases before the Court, without first utilising the procedures of article 55 of the Charter". ${ }^{35}$ In determining whether or not the Court would consider such a case the admissibility principles articulated in article 56 of the ACHPR would apply. ${ }^{36}$ This direct access does not exist under the current Protocol; the role of bringing this type of claim to the Court arguably rests with the Commission, where direct access is not possible. ${ }^{37}$

Article 20(1) of the ICJ Protocol.

Article 20(2) of the ICJ Protocol.

Rule 118(3) of the Rules of the Commission; see para 5 below. 
At the $30^{\text {th }}$ Ordinary Session of the Assembly of Heads of State and Government the OAU finally got involved and requested the OAU SecretaryGeneral to:

[C]onvene a meeting of government experts to ponder in conjunction with the Commission (...) over the means to enhance the efficiency of the Commission in considering particularly the establishment of a Court of Human and Peoples' Rights. ${ }^{38}$

Thus, in 1995 a second draft ${ }^{39}$ (hereafter the Cape Town Protocol) was put forward, which for the first time saw the direct involvement of the OAU. ${ }^{40}$ In this document an important revision was made to the contents of article 19(2) of the ICJ Protocol. Article 8(2) of the Cape Town Protocol noted that the Court should "not consider a case originating under the provisions of article 55 of the Charter until the Commission has considered the matter and prepared a report or taken a decision" [emphasis added]. Like the ICJ Protocol, the Cape Town Protocol established that the Commission could petition the Court and that under extraordinary circumstances to be determined by the Court, individuals, groups and NGOs could petition the Court without having to go through the Commission. An important distinction was made, however: the Court would have jurisdiction over a referral either after a decision by the Commission (as in the ICJ Protocol) or after the Commission had furnished a report. This opened up the possibility of the Commission comprehensively considering the matter on procedure or on procedure and merits. It could then either take a decision on the matter or report to the Court on its partial findings. Thereafter it could ask the Court to further engage with the matter.

From these two drafts it is evident that the Commission would have the primary say in most individual petitions, except in extraordinary cases. It is also apparent that the Court would entertain communications originating under article 55 of the ACHPR only after the Commission had considered the matter and taken a decision or completed a report. Hence, the Cape Town Protocol opened up an alternative to a comprehensive consideration by the Commission. ${ }^{41}$ Referring a communication to the Court after considering the case in full would arguably engage the Court under art 19(2)

38 Resolution on the Commission on Human and Peoples' Rights AHG/Res.230 (XXX) (1994).

39 Second Draft Protocol to the African Charter On Human and Peoples' Rights on the Establishment of a Court of Human and Peoples' Rights OAU/LEG/ EXP/AFCHPR/PRO(I) (1995).

$40 \quad$ Pityana 2004 AHRLJ 122.

41 Article 8(2) of the Cape Town Protocol. 
in a fashion similar to that in which the IACHR engages the IAC, ${ }^{42}$ as is further discussed under paragraph 5 below. The measure of a report would arguably be an alternative where the admissibility and prima facie jurisdiction could be considered in accordance with article 56 of the ACHPR. The Cape Town Protocol is silent on what type of report (i.e. the necessary contents of the report) the Commission would be required to issue, and where the report would be destined to go. Clearly the reference in article $8(1)$ referring to article 52 of the ACHPR foresees a report stating the facts and findings to be sent to the concerned states and communicated to the Assembly. No such reference is made in 8(2), which therefore does not constrict the Commission to report to the Assembly. Such a report could set out the facts and the admissibility of the case at hand together, as indicated above, with an explanation as to why the Commission sought the involvement of the Court.

In April 1997, the year before the adoption of the current Protocol, another drafting exercise was held in Nouakchott, Mauritania. This meeting produced the Nouakchott Protocol, which further elaborates on the positioning of the Commission and the Court in the new hierarchy. ${ }^{43}$ In article 5(1)(a) of the Nouakchott Protocol the Commission retained the competence to petition the Court. Through article 6 the avenue for individuals and NGOs (with the added requirement of "observer status") remained open in urgent cases or cases of serious, systematic or massive violations of human rights. In cases of this character the Court was obliged to "request[s] the opinion of the Commission which must give it as soon as possible". 44 The Court was set to rule on the admissibility of communications instituted by individuals, groups and NGOs, taking into account the provisions of article 56 of the ACHPR. The Court could furthermore consider the case or transfer it to the Commission.

Article 6(5), in addition, importantly introduced the structure that would later be transformed into the 34(6) declaration and the locus standi requirement proclaimed in art 5(3) of the Protocol. ${ }^{45}$ Article 8(2) of the Nouakchott Protocol was kept identical to that in the Cape Town Protocol.

\footnotetext{
42 See para 4 below.

43 Third Draft Protocol to the African Charter on Human and Peoples' Rights on the Establishment of a Court on Human and Peoples' Rights OAU/LEG/ EXP/AFCHPR/PRO(2) (1997).

44 Article 6(2) of the Nouakchott Protocol.

45 Article 6(5) of the Nouakchott Protocol reads: "At any time after the ratification of this Protocol, the state must make a declaration accepting the competence of the Court to
} 
The last push to establish the Protocol was undertaken in December 1997, when the Addis Ababa Protocol was finalised. ${ }^{46}$ After a lengthy debate on article 8 the state parties represented concluded that article 8 , as it had previously been formulated, did not cater for all the types of cases that could be brought before the Court. ${ }^{47}$ Accordingly, they decided that the heading and body of the article be amended. A new, single paragraph replaced the previous four paragraphs, and the word "Communications" in the heading was changed to "Cases". After this considerable re-draft it was presented before the state parties and unanimously adopted. ${ }^{48}$

The final Protocol establishing the Court cements the importance of complementarity but defers the problem of defining it. However, it is importantly stipulated in article 33 of the Protocol that the Court, in drawing up its rules and procedures, should consult the Commission as appropriate. As noted by Elsheikh, this "consultation" would be essential in relation to articles 5(1) and 6 of the Protocol, which are concerned with the direct relationship between the Commission and the Court. ${ }^{49}$

\section{The complementarity arrangement and the referral of complaints under the Inter-American system}

To further contextualise the processes and procedures surrounding referrals, I seek to draw some distinctions and parallels between the InterAmerican human rights machinery set up under the American Convention on Human Rights ${ }^{50}$ (hereafter the ACHR) and the institutions set up under the ACHPR and the Protocol. Contrary to the ACHPR, the ACHR establishes both the IACHR and the IAC as organs that "shall have competence with respect to matters relating to the fulfilment of the commitments made by the States Parties". However, the authority of the IACHR to receive and hear individual complaints depends on a declaration

receive petitions under the first paragraph of this article. The Court shall not receive any petition involving a State Party which has not made such a declaration".

46 Fourth Draft Protocol to the African Charter on Human and Peoples' Rights on the Establishment of a Court on Human and Peoples' Rights OAU/LEG/EXP/AFCHPR/PROT (III) Rev 1 (1997).

47 Report of the $3^{\text {rd }}$ Government Legal Experts Meeting Enlarged to Include Diplomats, para VII Consideration of Articles, art 8, OAU/LEG/EXP/AFCHPR/RPT (III) Rev 1 (1997).

48 Report of the $3^{\text {rd }}$ Government Legal Experts Meeting Enlarged to Include Diplomats, para VII Consideration of Articles, art 8, OAU/LEG/EXP/AFCHPR/RPT (III) Rev 1 (1997).

49 Elsheikh 2002 AHRLJ 258.

50 American Convention on Human Rights (1969). 
by each state party, that it recognises this competency. ${ }^{51}$ Furthermore, all cases before the IAC are dependent on a declaration by each state party to the ACHR to the effect that it recognises the IAC's jurisdiction pertaining to the interpretation or application of the ACHR. ${ }^{52}$ By way of explanation, the jurisdiction of both organs is restricted by the sovereign decision of state parties, whereas access to the Commission is not linked to a declaration of this sort. As states ratify the ACHPR they recognise the competency of the Commission to receive, hear and decide complaints received from individuals, while the jurisdiction of the Court in this regard is restricted only by the optional jurisdiction set out under article 34(6) of the Protocol.

Moreover, under the American system the IACHR is the only body that can bring claims of violations of the rights of individuals to the IAC. ${ }^{53}$ The jurisdiction of the IAC, as per the declaration of state parties, does not per se provide individuals and NGOs with locus standi. In contrast, the Protocol does not contain an adjudicatory jurisdiction clause but limits the optionality to a decision on whether states will allow for individuals and NGOs with observer status before the Commission to gain direct access to the Court. It could be argued that since the Court is established through a separate Protocol, and not through the ACHPR, the decision to ratify the Protocol follows the same pattern as the adjudicatory jurisdiction clause in the ACHR. In both cases states have the option to ratify the main human rights instruments (the ACHR and the ACHPR) without running the risk of being exposed to the jurisdiction of the related courts. The noteworthy difference however is that the competency of the Commission is non-negotiable for any member state to the ACHPR.

Against this background and in analysing the relationships between the Commission and Court on the one hand and on the other the IACHR and the IAC, it is important to acknowledge the similarities between the role of the Commission as set out in rule 118(1) of the Rules of the Commission and the role designated to the IACHR under the ACHR. Under rule 118(1), the Commission may bring a case to the Court if it has taken a decision with respect to a communication submitted under articles 48,49 or 55 of the ACHPR and it considers that the state has not complied or is unwilling to comply with its recommendations within 180 days. ${ }^{54}$ This approach is similar to and comparable with the Inter-American system, with some important differences, as pointed out below. The ACHR, as mentioned above, allows

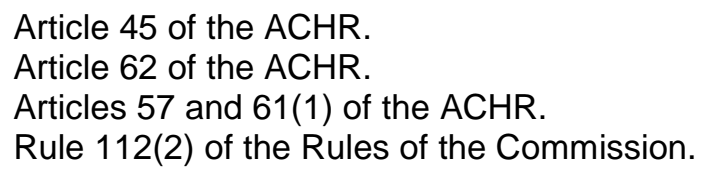


state parties and the IACHR to file complaints with the IAC only under article 61 , whereas direct complaints by individuals are enabled by the article 34(6) declaration under the Protocol. According to article 61(2) of the ACHR, the procedure in articles 48 (an examination of the case and trying to reach a friendly settlement) and 50 (where a friendly settlement is not reached) have to be exhausted before the IACHR can lodge such a complaint. ${ }^{55}$

To elaborate on the relationship between the IACHR and the IAC, the Rules of Procedure of the IACHR (hereafter the Rules of the IACHR) have been established. Rule 44 of the Rules of the IACHR stipulates that the IACHR has to furnish a report on the merits of each case. The complainant has to be informed of the report and in cases where a respondent state has accepted the contentious jurisdiction of the IAC the complainant has an opportunity to present his or her position as to whether the case should be submitted to the IAC. ${ }^{56}$ Rule 45 of the Rules of the IACHR sets out the further procedure for such a referral. If the State in question has accepted the jurisdiction of the IAC, in accordance with article 62 of the $A C H R$, and the IACHR considers that the State has not complied with the recommendations of the report approved in accordance with article 50 of the ACHR, it must refer the case to the Court, unless there is a reasoned decision by an absolute majority of the members of the IACHR to the contrary. In making this decision the IACHR should, amongst other things, take the position of the petitioner into consideration. Importantly, when the IACHR decides to bring a case before the IAC it must submit a copy of the report adopted pursuant to article 50 of the ACHR, accompanied by a copy of the file before the IACHR, excluding any internal working documents and including any other document deemed useful for the analysis of the case. Under the Inter-American system a referral thus takes place within a process with better-defined roles of the two institutions involved. ${ }^{57}$

55 See also art 47 of the European Convention on Human Rights (1950), which indicated that the European Court (before its merger with the Commission) could deal with a case only after the Commission had acknowledged the failure of efforts to bring about a friendly settlement.

56 Rule 44(3) of the Rules of the IACHR stipulates that: "When the petitioner is interested in the submission of a case, he or she should present the following: a) the position of the victim or the victim's family members, if different from that of the petitioner; b) the reasons he or she considers that the case should be referred to the Court; and c) the claims concerning reparations and costs."

57 This is not to say that the Inter-American system is without is flaws and problems. See for example Viljoen 2004-2005 Brook J Int'I L 25 referring to Padilla 2002 AHRLJ 191, where it is indicated that although the IAC was established in 1980, it received its first contentious case in 1986 only and its second case 4 years later. 
This is similar to the position of the Commission under rule 118(1) of the Rules of the Commission and the preparatory work, as discussed above. Under this rule the Commission finalises a case both on procedure and merits, and it is the state's response (or lack of response) that triggers the jurisdiction of the Court. However, one important difference from the procedure of the IACHR is the clear reference to the petitioners' input in the Rules of the IACHR. No such provision exists under the Rules of the Commission, which leaves the position of a petitioner undefined when a case is referred to the Court.

\section{The principle of complementarity in the process of referrals in the African system}

As mentioned in the introduction, the preamble to the Protocol spells out that the Court should "complement and reinforce the functions of the Commission". Under the Protocol the relationship between the Commission and the Court, the right to petition (locus standi) and the instruction to the Court in the consideration of referrals are set out in articles 2, 5(1)(a) and 8. Article 2 spells out the encompassing principle of complementarity. It states that:

The Court shall, bearing in mind the provisions of this Protocol, complement the protective mandate of the Commission on Human and Peoples' Rights

(...) conferred upon it by the African Charter on Human and Peoples' Rights.

In accordance, article 8 of the Protocol establishes that:

The Rules of Procedure of the Court shall lay down the detailed conditions under which the Court shall consider cases brought before it, bearing in mind the complementarity between the Commission and the Court.

It is clear that the compounded relationship between the Commission and the Court remains undefined under the Protocol and that power has been vested in these institutions to deconstruct and unravel these complexities. As was decided in Addis Ababa, it is up to the Commission and the Court to implement rules of procedure to provide further guidance in this regard.

Central to this discussion, Elsheikh points to the idea that:

The Court would not admit a case before the Commission has acted upon it, as the role of the Court would be that of appeal against the decision of the Commission. ${ }^{58}$ 
In this regard the former Commissioner spoke not about the powers of the Commission but about the jurisdiction of the Court to hear cases brought to it under articles 5(1)(b) (relating to an inter-state complaint) and 5(1)(c) (relating to inter-state complaints and complaints made under article 55 of ACHPR appealed by a state party) of the Protocol. In other words, if the Commission has been engaged under the ambit of its protective mandate under the ACHPR, either through an inter-state or "other" complaint, the Commission would have to make a decision on the matter before the Court would gain jurisdiction with due regard to the complementarity principle. Elsheikh rests his conclusions on the supremacy of the Commission in the drafting history of article 8 , which I related to above in paragraph 3 .

However, this does not settle how the Commission should approach referrals of individual complaints under article 5(1)(a) in the light of the complementarity principle. In this regard it is not, in my opinion, too farfetched to apply the same line of thinking, as expressed by Elsheikh, to cases brought directly from the Commission to the Court under article

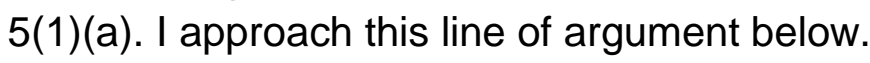

\subsection{Referrals by the Commission}

As briefly mentioned above, rule 118 of the Rules of the Commission offers four different conditions under which the Commission can refer an individual communication originating under article 55 of the ACHPR to the Court. ${ }^{59}$ Firstly, the Commission can refer a case to the Court under rule 118(1) if a state party is unwilling to comply with the recommendations of the Commission within the stated timeframe. In this case, as established by Viljoen, the Commission has finalised the case and the process could, if utilised, resemble that of the IACHR's in its referrals to the IAC, as discussed above under paragraph 4 .

Secondly, if the Commission has made a request for provisional measures against a state party in accordance with rule 98 of the Rules of the Commission, and it considers that the state has not complied with the request, the communication may be transferred under rule 118(2). In this case the matter has not been finalised by the Commission and two different outcomes are possible; either the Court decides on the provisional

59 It is pertinent to note that rule 118(1) of the Rules of the Commission does not refer only to individual claims but makes reference to inter-state complaints under arts 48 and 49 of the ACHPR. 
measures and sends the case back to the Commission or retains the case to make a decision in entirety. ${ }^{60}$

Thirdly, if a situation that constitutes one of serious or massive violations of human rights, as provided for under article 58 of the ACHPR, has come to the attention of the Commission, it may transfer it to the Court under rule 118(3).

Lastly, the Commission may, under rule 118(4), seize the Court at any stage of the examination of a communication if it deems it necessary to do so.

Under rule $118(1)$ it is clear that the Commission has finalised the matter. A decision has been made on both procedure and merits and this approach clearly fits within the discussion of the preparatory works above. It also resembles the procedure used in the Inter-American system. It seems to clearly delineate the functions of the two institutions. I will therefore not engage further with this procedure.

However, with regard to (2), (3) and (4) it is clear that the Commission can have had little, very little or no engagement with the matter before it is referred. This is, as pointed out by Viljoen, ${ }^{61}$ probably "informed by the fact that the Protocol does not explicitly require the Commission to make a finding on the admissibility and merits of a case before submitting it to the Court". This, I argue, is an outcome of the re-drafting that occurred in Addis Ababa, as discussed under 3 above, resulting in the undefined instruction in article 8 of the Protocol. This is specifically highlighted by rules 118 (3) and (4), where the real conduit mechanism is created. As I am particularly interested in this "conduit process" I refer mainly to rule 118(3) and (4) in the discussion below.

Before I engage with the process of referrals it is important to try to establish the differences between rules 118(3) and (4) of the Rules of the Commission. The first basic difference is the qualifications set out in (3) of "serious or massive violations" and the lack of qualifications and reference to "necessary" in (4). Viljoen suggests that (3) is distinguishable from (4) in that (3) would enable the Commission to bring a "case" to the Court on its own initiative based on information provided either by an individual, a group or a NGO, or obtained through any other channel. ${ }^{62}$ However, there could be, I suggest, an alternative interpretation. As all 4 sub-sections refer to

\footnotetext{
Viljoen International Human Rights Law in Africa 428.

Viljoen International Human Rights Law in Africa 428.

Viljoen International Human Rights Law in Africa 428-429.
} 
"communications", I propose that what can be referred to the Court are only complaints submitted to the Commission in accordance with the ACHPR, which are then acted upon by the Commission as the various sub-sections prescribe. Rule (3) reads:

The Commission may, pursuant to Rule 84(2) submit a communication before the Court against a State Party if a situation that, in its view, constitutes one of serious or massive violations of human rights as provided for under Article 58 of the African Charter, has come to its attention.

It refers to rule 84(2) of the Rules of the Commission, which confirms that in conformity with article 5(1)(a) of the Protocol and rule 118(3) the Commission may refer "the matter" to the Court. Based on the reference to "has come to its attention" and "the matter" Viljoen supports the conclusion that the Commission's mandate to bring human rights violations to the Court has gone beyond matters that have been duly filed at the Commission as complaints. This, I suggest, is contradicted by the reference to "one or more communications" in rule 84(1) and the reference to "a communication (...) against a state party" in rule $118(3) .{ }^{63}$

This matter is further complicated by the fact that rule 118(3) refers to article 58 of the ACHPR. Article 58 seems to indicate that in this type of case the Commission does not have to formally make a decision on the matter to be able to pass it on. Article 58 refers to "[w]hen it appears after deliberations of the Commission", which could imply that a discussion at the Commission without a formal decision is enough to hand the matter over to the Assembly of Heads of State and Governments. However, it is unclear whether this has any bearing on the process before the Commission in reference to a referral to the Court. Is a deliberation without a decision enough to spark the transfer of the case to the Court in this regard? My interpretation of the reference in (3) to article 58 of the ACHPR is that this reference serves to substantiate the nature of the violation rather than the process, and that in cases relating to this type of grave violations the Commission has a choice either to follow the procedure set out in article 58 of the ACHPR or use the process to engage the Court. In engaging the Court, I argue that all four sections of rule 118 are (unfortunately) dependent on an initial complaint. I acknowledge, however, that with regard to (3) the process is indistinct and open for interpretation. This is furthermore buttressed by the fact that the interim Rules of Procedures of the Commission have opened up an avenue 
for the Commission to consider situations without the reference to a specific communication. ${ }^{64}$

In continuation I argue that rules (3) and (4) overlap and that there are types of communications that would not fit under (3) that would still necessitate a referral under (4). Viljoen has suggested that urgency is the main impetus of rule 118(4). These would be very specific communications, considering the scope of rule 118(3) covering serious or massive human rights violations. Arguably there is great overlap between "serious" and "urgent", as is also acknowledged by Viljoen in referring to communications triggering rule $118(3)$ as cases of "extreme gravity and urgency". ${ }^{65}$ Considering this, the reference to urgency under (4) seems to be somewhat redundant as many of these communications would fit under (3).

What other types of communications remain? I would like to return to the idea under (4) of the unqualified conduit and the necessity of a referral that is determined by the Commission itself. In this regard it is also relevant to remember the reasons why the Commission would want to refer a communication to the Court, as mentioned above under paragraph 2 . Considering the distinct "toolbox"66 available to the Court it could arguably be better situated to deal with some communications where the Commission has had previous experience of the state involved as not adhering to its decisions in similar matters. This is one of the plausible reasons why the Commission referred the situation of the Ogiek people of the Mau Forest to the Court in 2011.67 In November 2009, on similar facts, the Commission had considered the Endorois case. ${ }^{68}$ The Commission found in favour of the applicant (the same NGO that brought the Ogiek case to the Commission). However, the Kenyan government had since done very little to uphold the

64 Rule 119(4) stipulates that: "[t]he Commission may also file with the Court a case against a State party that has ratified the African Court Protocol if a situation has come to its attention that, in its view, constitutes one of serious and massive violations of human rights as provided for under Article 58 of the African Charter".

65 Viljoen International Human Rights Law in Africa 429.

66 The procedures that the Court offers beyond those available to the Commission consist of: hearings conducted in public (art 10(1)); any party to a case shall be entitled to be represented by a legal representative, including free legal representation of the party's choice (art 10(2)); any person, witness or representative of the parties appearing before the Court enjoys protection and all facilities necessary for the discharging of their functions, tasks and duties in relation to the Court (art 10(3)); the Court may receive written and oral evidence including expert testimony (art 26(2)); and, importantly, if the Court finds that there has been a violation of human or peoples' rights, it shall make appropriate orders to remedy the violation, including the payment of fair compensation or reparation (art 27(1)) of the Protocol.

67 African Commission on Human and Peoples' Rights v Kenya Application No 006/2012.

68 Centre for Minority Rights Development v Kenya 2009 AHRLR 75 (ACHPR 2009). 
findings of the Commission. In November 2013 the Commission issued a resolution calling on Kenya to implement its recommendations. ${ }^{69}$ In September 2014 the Kenyan President established a task force to deal with the Commission's decision. It has not, however, yielded any results yet. ${ }^{70}$ The necessity in a case like this would arguably rest on the enforcement of the final decision. This prompts the question of whether bringing a case to the Court would yield enforcement or compliance. Murray and Long, ${ }^{71}$ as well as Juma, ${ }^{72}$ provide some useful insight in this regard. They point out that it is not the binding nature ${ }^{73}$ of the judgement that increases the likelihood of enforcement but rather that an additional body would interpret the provisions of the ACHPR which, in their opinion, would strengthen the findings of the Commission. Murray and Long ${ }^{74}$ add that the procedures of the Court to achieve compliance are ultimately stronger than those of the Commission. Importantly, the Court can and should make appropriate orders to remedy the violation, including the payment of fair compensation or reparation, if it finds any violation of the rights set out in the ACHPR. ${ }^{75}$

\subsection{Complementarity in the context of referrals under rules 118(3) and (4)}

The discussion below focuses on referrals (i) in the context of a situation that constitutes one of serious or massive violations of human rights; and (ii) that takes place in accordance with the necessity established by the Commission. With regard to the latter I consider the scenarios set out above i.e. where the state has ignored previous decisions by the African Commission, and cases where the specific competence, measures or remedies of the African Court are required.

Rules 118(3) and (4) of the Rules of the Commission seemingly allow for the Commission to be just a conduit; a method clearly refuted by the majority of the preparatory works, as discussed above under paragraph 3 . As is clear from the analysis by Elsheikh, which is also referred to above, everything in the preparatory works of the Protocol seems to point to some sort of a decision by the Commission before the Court can assume jurisdiction. ${ }^{76}$

69 Resolution Calling on the Republic of Kenya to Implement the Endorois Decision, the Commission on Human and Peoples' Rights ACHPR/Res.257 (2013).

African Commission on Human and Peoples' Rights 2015 http://bit.ly/23gUgjb.

Murray and Long Implementation of the Findings of the African Commission 143-151. Juma 2012 Wis Int'l LJ 351.

Article 30 of the Protocol.

Murray and Long Implementation of the Findings of the African Commission 143.

Article 27(1) of the Protocol.

See para 3 above. 
However, under rules 118(3) and (4) no decision or report is required. This brings me back to a consideration of what result an application of the complementarity principle would produce within the ambit of these two conduit scenarios.

Arguably the two types of scenarios referred to above are differently initiated. In the first case the need for the urgent consideration of grave violations by the Court emanating in a legally binding decision may be one motivation. In the second scenario a legally binding decision vis-à-vis a previously unresponsive party and/or the need for a specific type of tool, expertise or remedy may possibly be the motivation. In both types of case it would forfeit the purpose of the referral if decisions on the merits were required. What I argue in favour of is not an in-depth involvement in the merits, which would in any event place the referral closer to rule 118(1), but instead a consideration of the admissibility of the case.

There are a number of reasons why the Commission should conduct an admissibility enquiry. The Commission would arguably be better situated to consider the admissibility of a communication submitted to it. Even though the mandates of the Commission and Court are similar, the experience of the Commissioners, with regard to the process of state reporting and the development of special mechanisms (special rapporteurs, working groups, missions and committees) could be utilised in the process of preparing a case before the Court. ${ }^{77}$ Furthermore, as entrenched in article 1 of the ACHPR, the over-arching aim of the Commission and Court is to uphold these rights. As many complaints submitted before the Commission (and the Court) are declared inadmissible, the Commission could play an important role in assisting the complainant in remedying any lack in the complainant's admissibility claims. ${ }^{78}$

A consideration and report on admissibility presented to the Court by the Commission could further alleviate the confusion as to the roles of the original complainants and the Commission when a case is referred to the Court. Within this context it is relevant to pay attention to the tension that is inevitably created in a system where two purportedly impartial adjudicators, the Commission guided by the ACHPR and the Court guided by the Protocol and the ACHPR, are to co-exist. As the Commission brings a complaint before the Court the proceedings are inexorably complicated by the possibility of the conflicting roles assumed by the Commission. As the

African Commission on Human and Peoples' Rights 2016 http://bit.ly/1r9bFhv.

Viljoen International Human Rights Law in Africa 303. 
Commission submits ${ }^{79}$ a case to the Court it acts as a litigant. ${ }^{80}$ However, cases referred to the Court are not generated by the Commission, and as such it arguably has to rely on the original party to some extent for information. As suggested by Murray and Long: ${ }^{81}$

\begin{abstract}
When submitting a case to the Court under Article 118(1) further evidence is going to be required on non-compliance specifically. The Commission is unlikely in practice to collate this itself, but rather it will be calling on the initial parties to provide what is necessary. In this context, the Commission arguably simply becomes a conduit through which the parties to the initial communication reach the Court.
\end{abstract}

It is not unlikely that the Commission, I argue, would take the same approach towards the substantiation of the existence of grave human rights violations. Therefore, even if the Commission is the de facto party before the Court it is still substantially connected to and would arguably have to rely on the complainants for information. In this role it has to try to combine both the victims' best interest and the interests of the over-all system, as it is guided by its mandate in article 45 of the ACHPR and the fundamental principle of state sovereignty. Thus far only three cases have been referred by the Commission to the Court, as indicated above. Therefore it is too early to be able to conclude exactly what role the Commission will assume before the Court. It is inevitable, however, that the Commission, in this process, is pitted against the state party accused of violating the ACHPR; and under those circumstances the independence of the Commission can be questioned. ${ }^{82}$

The main implication of rules 118(3) and (4) of the Rules of the Commission is that they contradict the idea of the reinforcement of the Commission's functions as stated in the preamble to the Protocol, as quoted above. It opens up the possibility of de novo consideration by the Court, which is particularly difficult in cases where the exhaustion of local remedies rule has been relaxed. ${ }^{83}$ However, whereas there might be good reasons for giving the Court the opportunity to pass judgement on the merits of the matter, I

79 See rule 118(1) "[the Commission] may submit the communication to the Court"; 118(2) "the Commission may (...) refer the communication to the Court"; 118(3) "the Commission may (...) submit a communication before the Court"; and 118(4) "the Commission may seize the Court".

80 Murray and Long Implementation of the Findings of the African Commission 156-157.

81 Murray and Long Implementation of the Findings of the African Commission 156.

82 Murray and Long Implementation of the Findings of the African Commission 157.

83 Both the Commission and the Court have declared communications and complaints admissible even though domestic remedies were not exhausted. See for example Jawara v The Gambia 2000 AHRLR 107 (ACHPR 2000) para 28-40; and Lohé Issa Konaté v Burkina Faso Application No 004/2013 para 77. 
argue that the complementarity principle and the procedure set out in the ACHPR should locate the primary consideration of the procedure at the Commission. A failure to undertake such considerations poses serious challenges to the Court with regard to the duplication of the measures taken and the misuse of resources.

The last step in this analysis is to put rules 118(3) and (4) within the context the Rules of the Court to further analyse any potential support for interpreting complementarity to promote an extended mandate of the Commission before a referral takes place. Rule 29 of the Rules of the Court gives expression to articles 2 and 8 of the Protocol. Rule 29(6) of the Rules of the Court confirms that for the Court to have jurisdiction over a communication that has been before the Commission, the Court shall ascertain that the said communication has been formally withdrawn. Furthermore, the evidence-related matters are set out in rule 29(3)(a-c) of the Rules of the Court. Rule 29(3)(a) spells out that when the Commission brings a case before the Court under article 5(1)(a) of the Protocol "its application shall be accompanied by its Report". This supports the idea of a "report" set out in the first three Draft Protocols.

In a referral of a communication, rules 120-122 of the Rules of the Commission equally apply. Rule 121(1) indicates that when, in pursuance of article 5(1)(a) of the Protocol, the Commission decides to bring a communication before the Court, it shall submit an application seizing the Court in accordance with the Rules of the Court (which requires a report under rule 29(3)(a)), accompanied by a summary of the communication and the communication file. It is unclear from the Rules of the Commission if the reference to a "summary of the communication and the communication file" is to be understood as the report reflected in rule 29(3)(a) of the Rules of the Court. It is evident that the two sets of Rules differ in the terminology used.

It is essential to further consider the implications of the lack of an admissibility and jurisdictional analysis by the Commission. If there is no such decision and no such report the Court will have to assert the admissibility of a complaint in relation to a party or parties that initiated the complaint at the Commission under article 55 of the ACHPR, even though the Commission, as discussed above, is formally the party to the case. It is incorrect to conclude that because the two bodies operate under the same admissibility criteria as set out in article 56 of the ACHPR it does not matter who performs the task of checking the admissibility of a claim. There is arguably a difference between the Commission's obligations under article 
56 of the ACHPR and the Court's obligations under article 6(2) and rule 40 of the Rules of the Court. The Commission "must" consider the criteria under article 56 of the ACHPR to make a decision under article 55, while the Court "shall" rule on the admissibility of cases "taking into account" the provisions of article 56 of the ACHPR under article 6(2) of the Protocol as referred to in rule 40 of the Rules of the Court. From this perspective it would make sense for the Court to receive a full admissibility report from the Commission that it could consider from the vantage point of not being completely bound by either the report or the full set of criteria. Furthermore, the Rules of the Court distinguishes between complaints brought by individuals and complaints brought by others (such as the Commission) as to what type of information needs to be furnished by the complainant. Rule 34(4) of the Rules of the Court indicates that an application should:

[S]pecify the alleged violation, evidence of exhaustion of local remedies or of the inordinate delay of such local remedies as well as the orders or the injunctions sought. All applications filed by individuals and Non-Governmental Organizations shall meet the other admissibility conditions as set out in article 56 of the Charter and Rule 40 of these Rules.

Clearly, an application filed by the Commission would have to abide by the first sentence referring only to the admissibility criteria set out under article 56(5) of the ACHPR. However, if the communication brought to the Court by the Commission is an individual complaint (the Commission is acting as a conduit under rule 118(3) or (4)) the other six conjunctive criteria in article 56 (1-4) and (6-7) are arguably relevant and must be decided upon. It is therefore my interpretation that a full admissibility check is necessary, but that the Rules of the Court rely on the principle of complementarity, as is further supported by article 6(1), in that they entrust the Commission to consider all the criteria, while the Court focuses specifically on the exhaustion of local remedies. Nevertheless, it would rest its decision on information brought forward by the Commission, if substantial enough. In this regard it makes sense to have the Commission undertake a full admissibility check based on the seven criteria and to present the Court with its findings where the Court would focus on the often complicated legal issues surrounding the exhaustions of local remedies. In this way complementarity would work to delineate the functions of the two institutions, which would arguably save time and resources. Another aspect of the Court's comprehensive involvement in the exhaustion of local remedies is that as the whole system rests on the fundamental principle of state sovereignty the Court is obliged to make sure that the domestic jurisdiction has been properly utilised before the regional remedies are sought. 


\section{Conclusion}

The point of departure of this article was the application of the principle of complementarity in the process of referring communications from the Commission to the Court. As stated by Elsheikh, ${ }^{84}$ a "[s]uccessful functioning of the Court would depend, among other things, on a viable Commission which works hand in hand with the Court". However, as I have shown above, complementarity is a messy business, if roles, mandates and tasks are not clearly set out. The fact that states could not agree on a more specific formula for the cooperation between the Commission and the Court is evidence of just how hard it is to apply complementarity and define it in real terms.

As I have argued above an unfettered application of rules 118(3) and (4) of the Rules of the Commission does not support complementarity. The idea of finalising the process pertaining to the procedure on the level of the Commission before approaching the next level of the Court, as set out in the Cape Town and Nouakchott Protocols, was arguably a good one. This is not, I argue, to say that we would always have to adopt the same approach as that taken in the Inter-American system, which is reflected in rule 118(1); where the Commission takes a decision on procedure and merits before a report is produced and referred to the Court. Arguably more flexibility was built into the African system. But to maintain the complementarity between these institutions it is crucial that the Commission applies articles 55 and 56 and undertakes a full procedural investigation before it refers a case to the Court under any of the avenues set out in rule 118(3-4). The fact that article 6(1) of the Protocol provides the Court with the opportunity to ask for the opinion of the Commission in cases initiated under article 5(3) could be seen to support this argument.

A referral by the Commission would in my opinion better fit with the principle of complementarity by (i) making sure that all admissibility issues are dealt with before the case is referred; and (ii) requiring the Commission to set out all its decisions and considerations in a report to constitute an integral part of the referral. This would arguably not only lessen the potential overlap between the Commission's and Court's investigations but it would also save the opposing party and the Court time and effort in delineating whether the claim has been properly conceived. I consider that the Commission would be better situated to undertake this type of enquiry as is so unmistakably

Elsheikh 2002 AHRLJ 253. 
indicated in article 6(1) of the Protocol, and that it could in fact support the original complainant in overcoming certain admissibility hurdles.

There will no doubt be cases where the Court would want to be more involved in the investigation of the procedure and process of the claim. However, in those cases a report on the admissibility of a claim would at least be a starting point. There will also, in all likelihood, be cases, as indicated above, where gravity and urgency would necessitate the swift action of the Commission and Court. However, as the instruments are formulated, all communications are conditional on admissibility, and even though there is a need to counteract the slow handling of cases at the Commission, excluding the consideration of admissibility from the process is not, I argue, the answer. There is no doubt that more financial and human resources could further facilitate the work of the Commission. However, it is when resources are not in place that the principles of complementarity should be applied in such a way as to maximise the resources available. This is one of the most important contributions of the principle of complementarity.

\section{Bibliography}

\section{Literature}

Clapham 2000 Hum Rts LJ

Clapham A "On Complementarity: Human Rights in the European Legal Orders" 2000 Hum Rts LJ 313-323

Ebobrah 2011 EJIL

Ebobrah S "Towards a Positive Application of Complementarity in the African Human Rights System: Issues of Functions and Relations" 2011 EJIL 663-688

Elsheikh 2002 AHRLJ

Elsheikh I "The Future of Relationship between the African Court and the African Commission" 2002 AHRLJ 252-260

Juma 2012 Wis Int'I LJ

Juma D " Provisional Measures under the African Human Rights System: The African Court's Order against Libya" 2012 Wis Int'l LJ 344-373 
Murray 2002 AHRLJ

Murray $\mathrm{R}$ "A Comparison Between the African and European Courts of Human Rights" 2002 AHRLJ 195-222

Murray and Long Implementation of the Findings of the African Commission Murray $\mathrm{R}$ and Long $\mathrm{D}$ The Implementation of the Findings of the African Commission on Human and People's Rights (Cambridge University Press Cambridge 2015)

Padilla 2002 AHRLJ

Padilla D "An African Human Rights Court: Reflections from the Perspective of the Inter-American System" 2002 AHRLJ 185-194

Pityana 2004 AHRLJ

Pityana NB "Reflections on the African Court on Human and Peoples' Rights" 2004 AHRLJ 121-129

Viljoen 2004-2005 Brook J Int'l L

Viljoen F "A Human Rights Court for Africa, and Africans" 2004-2005 Brook $J$ Int'l L 1-66

Viljoen International Human Rights Law in Africa

Viljoen F International Human Rights Law in Africa $2^{\text {nd }}$ ed (Oxford University Press Oxford 2012)

\section{Case law}

Article 19 v Eritrea 2007 AHRLR 73 (ACHPR 2007)

Centre for Minority Rights Development v Kenya 2009 AHRLR 75 (ACHPR 2009) (Commission on Human and Peoples' Rights)

Commission on Human and Peoples' Rights $v$ Libya Application No 004/2011 (African Court on Human and Peoples' Rights)

Commission on Human and Peoples' Rights $v$ Kenya Application No 006/2012 (African Court on Human and Peoples' Rights)

Commission on Human and Peoples' Rights $v$ Libya Application No 002/2013 (African Court on Human and Peoples' Rights)

Jawara v The Gambia 2000 AHRLR 107 (ACHPR 2000) (Commission on Human and Peoples' Rights) 
Lohé Issa Konaté v Burkina Faso Application No 004/2013 (Court on Human and Peoples' Rights)

\section{International instruments}

African Charter on Human and Peoples' Rights (1981)

American Convention on Human Rights (1969)

Charter of the Organisation of African Unity (1963)

Constitutive Act of the African Union (2000)

European Convention on Human Rights (1950)

First Draft Additional Protocol to the African Charter On Human and Peoples' Rights (1994)

Fourth Draft Protocol to the African Charter on Human and Peoples' Rights on the Establishment of a Court on Human and Peoples' Rights OAU/LEG/EXP/AFCHPR/PROT (III) Rev 1 (1997)

Protocol to the African Charter on Human and People's Rights on the Establishment of a Court on Human and People's Rights (1998)

Report of the 3rd Government Legal Experts Meeting Enlarged to Include Diplomats, para VII Consideration of Articles, art 8, OAU/LEG/EXP/AFCHPR/RPT (III) Rev 1 (1997)

Resolution on the Commission on Human and Peoples' Rights AHG/Res.230 (XXX) (1994)

Resolution Calling on the Republic of Kenya to Implement the Endorois Decision, the Commission on Human and Peoples' Rights ACHPR/Res.257 (2013)

Rules of Procedure of the African Commission on Human and Peoples' Rights (2010)

Rules of Procedure of the Inter-American Commission on Human Rights (2013)

Rules of the African Court on Human and Peoples' Rights (2010) 
Second Draft Protocol to the African Charter On Human and Peoples' Rights on the Establishment of a Court of Human and Peoples' Rights OAU/LEG/EXP/AFCHPR/PRO(I) (1995)

Third Draft Protocol to the African Charter on Human and Peoples' Rights on the Establishment of a Court on Human and Peoples' Rights OAU/LEG/EXP/AFCHPR/PRO(2) (1997)

\section{Internet sources}

African Commission on Human and Peoples' Rights 2015 http://bit.ly/23gUgjb

African Commission on Human and Peoples' Rights 2015 Statement by Endorois Welfare Council-Kenya at the $56^{\text {th }}$ Ordinary Session of the $21^{\text {st }}$ of April to $7^{\text {th }}$ May 2015 Banjul http://bit.ly/23gUgjb accessed 5 September 2015

African Commission on Human and Peoples' Rights 2016 http://bit.ly/1r9bFhv

African Commission on Human and Peoples' Rights 2016 List of Special Mechanisms Set Up Under the Auspices of the African Commission on Human and Peoples' Rights http://bit.ly/1r9bFhv accessed 20 April 2016

\section{List of Abbreviations}

$\mathrm{ACHR}$

ACHPR

AU

AHRLJ

Brook J Int'I L

EJIL

Hum Rts LJ

IAC

IACHR

ICJ

NGOs

OAU

Wis Int'I LJ
American Convention on Human Rights

African Charter on Human and Peoples' Rights

African Union

African Human Rights Law Journal

Brooklyn Journal of International Law

European Journal of International Law

Human Rights Law Journal

Inter-American Court of Human Rights

Inter-American Commission on Human Rights

International Commission of Jurists

Non-governmental organisations

Organisation of African Unity

Wisconsin International Law Journal 


\section{List of Short Titles}

Addis Ababa Protocol

Commission

Court

Cape Town Protocol

ICJ Protocol

Nouakchott Protocol

OAU Charter

Protocol

Rules of the IACHR

Rules of the Commission

Rules of the Court
Draft Protocol to the African Charter on Human and Peoples' Rights on the Establishment of a Court on Human and Peoples' Rights (December 1997)

African Commission on Human and People's Rights

African Court on Human and Peoples' Rights

Draft Protocol to the African Charter on Human and Peoples' Rights on the Establishment of a Court of Human and Peoples' Rights (1995)

[ICJ] Draft Additional Protocol to the African Charter On Human and Peoples' Rights (1994)

Draft Protocol to the African Charter on Human and Peoples' Rights on the Establishment of a Court on Human and Peoples' Rights (April 1997)

Charter of the Organisation of African Unity Protocol to the African Charter on Human and Peoples' Rights on the Establishment of a Court on Human and Peoples' Rights Rules of Procedure of the Inter-American Commission on Human Rights

Rules of Procedure of the African Commission on Human and Peoples' Rights

Rules of the African Court on Human and Peoples' Rights 